Gut, 1963, 4, 20

\title{
Liver disease and ammonia intoxication
}

\author{
KENNETH S. WARREN AND STEVEN SCHENKER \\ From the U.S. Department of Health, Education and Welfare, Public Health Service, \\ National Institutes of Health, National Institute of Allergy and Infectious \\ Diseases ${ }^{1}$, Bethesda, Maryland, U.S.A.
}

EDITORIAL SYNOPSIS The relation between ammonia intoxication and liver disease is not clear. Ammonia appears to be relatively non-toxic to normal individuals, whereas some patients with liver disease appear to be exquisitely sensitive to dietary protein, ammonia-releasing substances, and ammonium salts. In an attempt to elucidate this relationship the intravenous $\mathrm{LD}_{\mathbf{5 0}}$ of ammonium chloride was determined in both normal mice and in those with liver disease produced by a variety of means. Parenchymal damage was created by acute and chronic carbon tetrachloride intoxication, a low-protein, lipotrope-deficient diet, and mouse hepatitis virus. Mice in which the portal vein had been partially ligated and those infected with Schistosoma mansoni developed portal-systemic collateral circulation. Groups of these mice were placed on high-protein diets and ammonia drinking water for periods as long as two months. A combination of both parenchymal damage and collateral circulation was induced in mice either by bile duct ligation or by a combination of schistosomiasis and acute carbon tetrachloride intoxication. When the above groups of mice with liver disease were compared with normal control mice in the same weight range, the $\mathrm{LD}_{50}$ of ammonium chloride showed no striking change.

The coma-engendering effects of ammonia in dogs with Eck fistulae and in man with liver disease have been studied extensively since the 1890 s and 1930 s respectively (Nencki, Pawlow, and Zaleski 1896; Van Caulaert, Deviller, and Halff, 1932). Ammonium salts appear to be relatively non-toxic to normal human beings and animals (Tyor and Wilson, 1958; Warren, 1962). However, very small alterations in the supply of exogenous ammonia may precipitate episodes of hepatic coma in some patients with either parenchymal liver disease or altered hepatic circulation (Schwartz, Phillips, Seegmiller, Gabuzda, and Davidson, 1954). The question has arisen, therefore, as to whether the brain of certain patients with liver disease undergoes metabolic or morphological changes which makes it more susceptible to a given amount of ammonia. This could be mediated through a liver-brain relationship in which a diseased liver is associated with cerebral changes, or through the stimulus of a chronically raised concentration of either ammonia or other toxic products from the gut in the peripheral circulation (Walshe, 1960; Sherlock, 1961). In order to elucidate the role of ammonia under the above conditions, liver disease of many types was produced in mice, and their

${ }^{1}$ Laboratory of Parasitic Diseases. response to the intravenous injection of ammonium chloride was assessed.

\section{MATERIALS AND METHODS}

The intravenous $\mathrm{LD}_{50}$ of ammonium chloride was determined in Swiss albino female mice in several different weight groups, as has been previously described (Warren, 1958). The lethal effect of ammonia was also determined in animals with liver disease produced by a variety of methods. Parenchymal liver damage followed the subcutaneous injection of a single dose of carbon tetrachloride $(0.1 \mathrm{ml}$.) or its inhalation until ataxia or unconsciousness occurred (within 30 to 60 seconds) five days per week over a period of 96 days (Daniel, Prichard, and Reynell, 1952). Another group of animals was placed on a low-protein, lipotrope-deficient $\operatorname{diet}^{2}$ for two weeks, and a further group was infected with the Manaker strain of mouse hepatitis virus (SE5409). A $20 \%$ liver suspension made from suckling mice infected with SE5409 was prepared in 5\% horse serum in Eagle's basal medium and was inoculated intraperitoneally into weanling mice.

Changes in the hepatic circulation were induced by portal vein ligation, a method adapted from one previously described in rats (Whitaker, 1946). A stylet from an 18 gauge needle was placed alongside the portal

${ }^{2}$ Fatty liver diet (components in grams per kilogram): Casein 80 , sucrose 678 , lard 150 , salts (HMW) 40 , vitamin B mixture 25 , calcium pantothenate 5 , L-cystine 2 , vitamins $A, D, K$ and $E$ in oil, $20 \mathrm{ml}$. 
vein, and a 4-0 silk suture was tied tightly around both the vein and the wire. The wire was then withdrawn. Extensive portal-systemic collateral circulation, including paraoesophageal varices and venous connexions between the mesenteric vessels and the inferior vena cava and left renal vein were observed in all of the animals within two weeks following the operation. Other mice were exposed to 130 cercariae of a Puerto Rican strain of Schistosoma mansoni. Perfusions of the portal venous system showed approximately 30 worms per mouse. Subsequent studies were performed on groups maintained on a normal laboratory diet and on a $40 \%$ protein diet $^{3}$. The drinking water of the latter group contained $160 \mathrm{mEq}$. of ammonium bicarbonate per litre.

Both parenchymal damage and gross hepatic circulatory changes were induced in two other groups of mice. One set of animals infected with Schistosoma mansoni for 13 weeks was also injected subcutaneously with $0 \cdot 1 \mathrm{ml}$. of carbon tetrachloride. The other group of mice underwent surgery in which the common bile duct was tied with 4-0 silk as close to the porta hepatis as possible.

Serum bilirubin was determined by an ultramicro adaptation of the method of Malloy and Evelyn (1937). Portal pressure was obtained by introducing a 23 gauge needle connected to a Sanborn pressure transducer and strain gauge amplifier and recorder into the portal vein.

Changes in size of the liver and spleen were measured by weighing these organs on a Shadowgraph balance with a direct-reading range of $2 \mathrm{~g}$. The presence of paraoesophageal varices was ascertained by thoracotomy and direct observation.

Statistically, $\mathrm{LD}_{50} \mathrm{~s}$ were calculated by the method of Cornfield and Mantel (1950). Since the various groups of mice with liver disease, some of them maintained for months, had different average body weights, control

${ }^{3}$ High-protein diet (components in grams per kilogram): Casein 400, sucrose 345 , lard 150 , salts (HMW) 40 , water-soluble vitamin mixture 40 , choline chloride 2 , L-cystine 3 , inositol $0 \cdot 2$, vitamins $A, D, K$, and $E$ in oil, $20 \mathrm{ml}$.
$\mathbf{L D}_{50} \mathrm{~s}$ were performed on normal mice in three weight groups (Table I). Some of the diseased animals fell into weight groups different from these, and therefore a straight line was fitted to the experimentally determined values, and the change in $\mathbf{L D}_{50}$ with weight was calculated over a range of 20 to $30 \mathrm{~g}$. The standard deviation of each of these $\mathrm{LD}_{50} \mathrm{~s}$ was assumed to be that of the closest experimentally determined $\mathrm{LD}_{50}$. The $97.5 \%$ confidence limits were then determined, and the $\mathrm{LD}_{50} \mathrm{~s}$ of the diseased animals were compared with those of normal control mice of a similar average weight. An overlap of the confidence limits indicated no significant difference between the values, whereas a gap between them was indicative of significance at the $5 \%$ level.

\section{RESULTS}

PARENCHYMAL LIVER DAMAGE The LD $_{50}$ of ammonium chloride was determined in mice 54 hours after the subcutaneous injection of carbon tetrachloride. One of the 58 animals injected was dead at that point, and the livers of the survivors showed severe generalized parenchymal damage (Fig. 1). Blood $p \mathrm{H}$ measurements performed by the method described by Warren (1958) revealed a slight rise in blood $p \mathrm{H}$, from a normal value of $7.50 \pm 0.024$ to $7 \cdot 55 \pm 0.018$. Nevertheless, the $\mathrm{LD}_{50}$ of ammonium chloride was almost identical to that of the normal controls (Table II).

After the inhalation of carbon tetrachloride over a period of 96 days the mice developed a form of cirrhosis in which there was moderate hepatomegaly unaccompanied by splenic enlargement. Microscopically, there were bands of fibrous tissue linking central veins, inflammatory cell infiltration, and frequent mitoses among the parenchymal cells

\section{TABLE I}

VARIATION WITH WEIGHT IN LD $_{50}$ OF AMMONIUM CHLORIDE IN NORMAL CONTROL MICE

\begin{tabular}{ccccc} 
Average Body Weight $(k g)$. & $L D_{50}$ & \pm & $S . D$. & Approximate 97.5\% Confidence Interval \\
\hline 20 & 717 & \pm & 30 & $650-784$ \\
24 & 800 & \pm & 21 & $753-847$ \\
29 & 850 & \pm & 36 & $770-930$
\end{tabular}

TABLE II

PARENCHYMAL DAMAGE AFTER LD $_{50}$ OF AMMONIUM CHLORIDE IN MICE WITH LIVER DISEASE

\begin{tabular}{|c|c|c|c|c|c|c|c|c|}
\hline & \multirow{2}{*}{$\begin{array}{l}\text { Average } \\
\text { Body } \\
\text { Weight } \\
(\text { kg.) }\end{array}$} & \multirow[t]{2}{*}{$\begin{array}{l}\text { Estimated } \\
L D_{50}\end{array}$} & \multirow[t]{2}{*}{ \pm} & \multirow[t]{2}{*}{ S.D. } & \multirow[t]{2}{*}{$\begin{array}{l}\text { Expected } \\
L D_{50}\end{array}$} & \multicolumn{2}{|c|}{$\begin{array}{l}\text { Approximate } 97.5 \% \\
\text { Confidence Limit for }\end{array}$} & \multirow[t]{2}{*}{$\boldsymbol{P}$} \\
\hline & & & & & & $\begin{array}{l}\text { Estimated } \\
L D_{50}\end{array}$ & $\begin{array}{l}\text { Expected } \\
L D_{\text {su }}\end{array}$ & \\
\hline $\begin{array}{l}\text { Acute carbon tetrachloride } \\
\text { Chronic carbon tetrachloride (96 days) } \\
\text { Fatty liver diet } \\
\text { Mouse hepatitis virus } \quad \text { Day } 3 \\
4 \\
5 \\
6\end{array}$ & $\begin{array}{l}23 \\
30 \\
23 \\
20 \\
20 \\
20 \\
20\end{array}$ & $\begin{array}{r}750 \\
1,028 \\
626 \\
646 \\
640 \\
633 \\
700\end{array}$ & $\begin{array}{l} \pm \\
\pm \\
\pm \\
\pm \\
\pm \\
\pm \\
\pm\end{array}$ & $\begin{array}{r}39 \\
38 \\
39 \\
13 \\
23 \\
24 \\
8\end{array}$ & $\begin{array}{l}765 \\
875 \\
765 \\
720 \\
720 \\
720 \\
720\end{array}$ & $\begin{array}{l}663-837 \\
943-1,113 \\
539-713 \\
617-675 \\
588-692 \\
579-687 \\
682-718\end{array}$ & $\begin{array}{l}718-812 \\
795-955 \\
718-812 \\
653-787 \\
653-787 \\
653-787 \\
653-787\end{array}$ & $\begin{array}{l}\text { Insignificant } \\
\text { Borderline significance } \\
<0.05 \\
\text { Insignificant } \\
\text { Insignificant } \\
\text { Insignificant } \\
\text { Insignificant }\end{array}$ \\
\hline
\end{tabular}




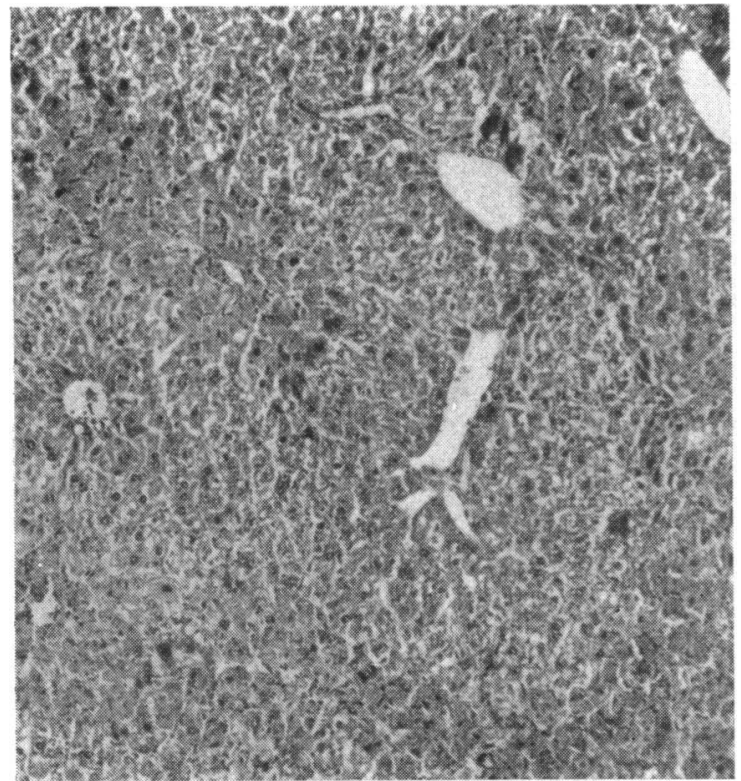

FIG. 1 .

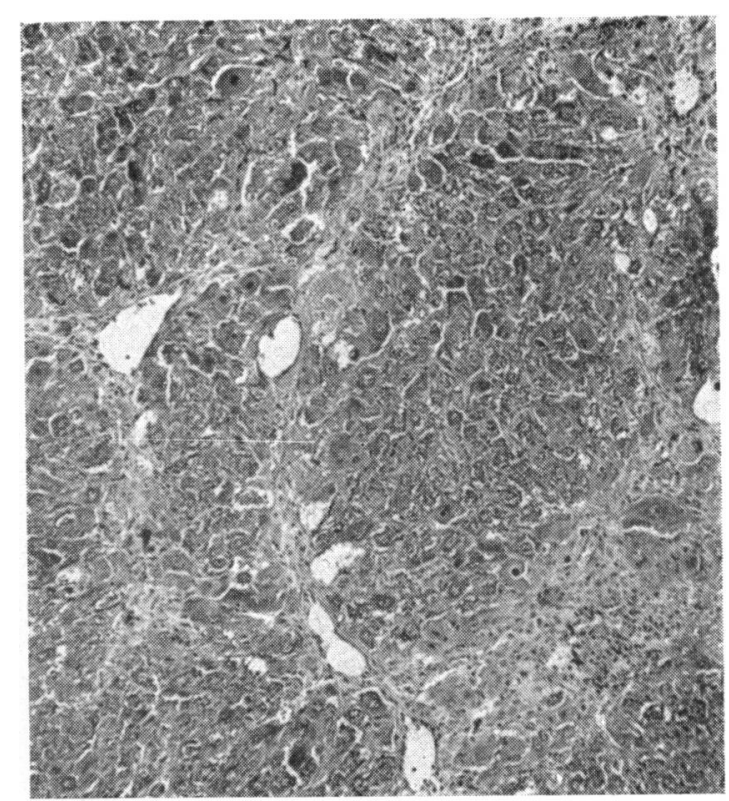

FIG. 2 .

FIG. 1. Liver 54 hours after the subcutaneous injection of $0 \cdot 1 \mathrm{ml}$. of carbon tetrachloride. Haematoxylin and eosin $\times 73$.

FIG. 2. Liver after the inhalation of carbon tetrachloride five days a week for 14 weeks. Mallory trichrome $\times 73$.

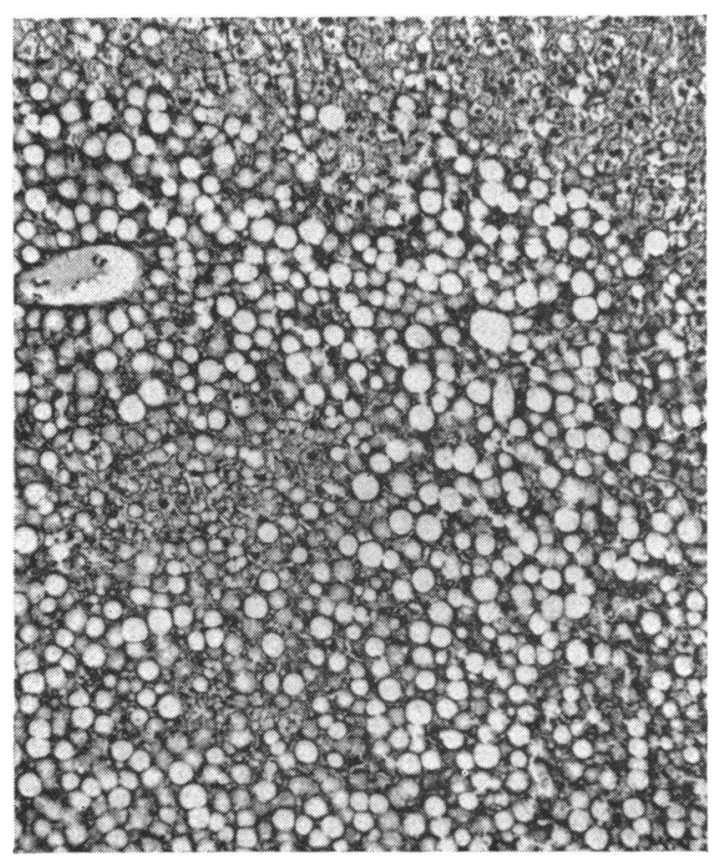

FIG. 3. Liver after two weeks on a low-protein, lipotropedeficient diet. Haematoxylin and eosin $\times 73$.
(Fig. 2). In addition there was moderate fatty infiltration as determined by staining with oil red 0 . Ammonium chloride at this time was less toxic to these animals than to normal mice in the same weight range (Table II).

Although mice placed on a low-protein, lipotropedeficient diet for two weeks showed no hepatomegaly there was marked fatty change (Fig. 3). Ammonia toxicity was slightly increased in these animals (Table II).

Mice infected with mouse hepatitis virus showed a daily increase in liver damage beginning about the third day. A group of 50 animals was concurrently infected with the experimental dose of virus in order to determine its lethal affect. Although there were no deaths on the third day, $14 \%$ were dead on the fourth day. By the fifth day the mortality rose to $58 \%$ and on the sixth day $76 \%$ of the animals were dead. On day three there was slight enlargement of the liver, which increased somewhat on day four, and then remained constant on the fifth and sixth days. Microscopic examination of the livers of mice that were sacrificed for that purpose revealed focal areas of necrosis infiltrated with inflammatory cells. These increased in size with time and by the sixth day there was widespread necrosis and fatty infiltration 


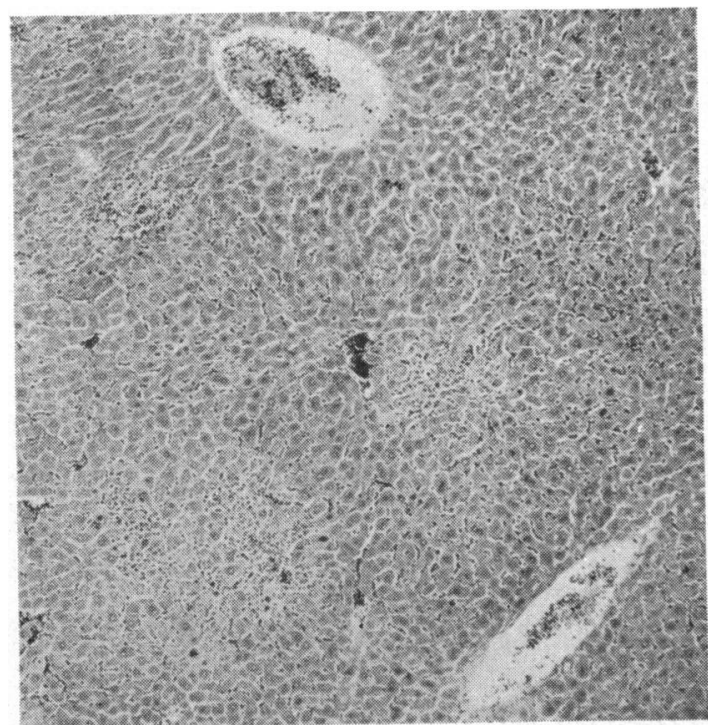

FIG. 4. Liver three days after infection with mouse hepatitis virus. Haematoxvlin and eosin $\times 73$.

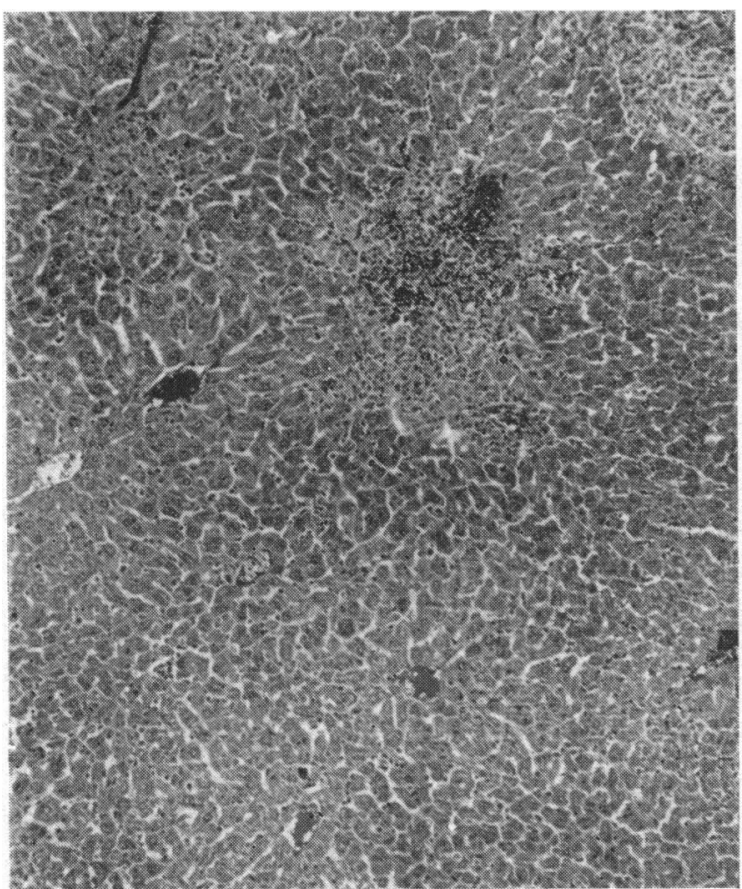

FIG. 6. Liver five days after infection with mouse hepatitis virus. Haematoxylin and eosin $\times 73$.

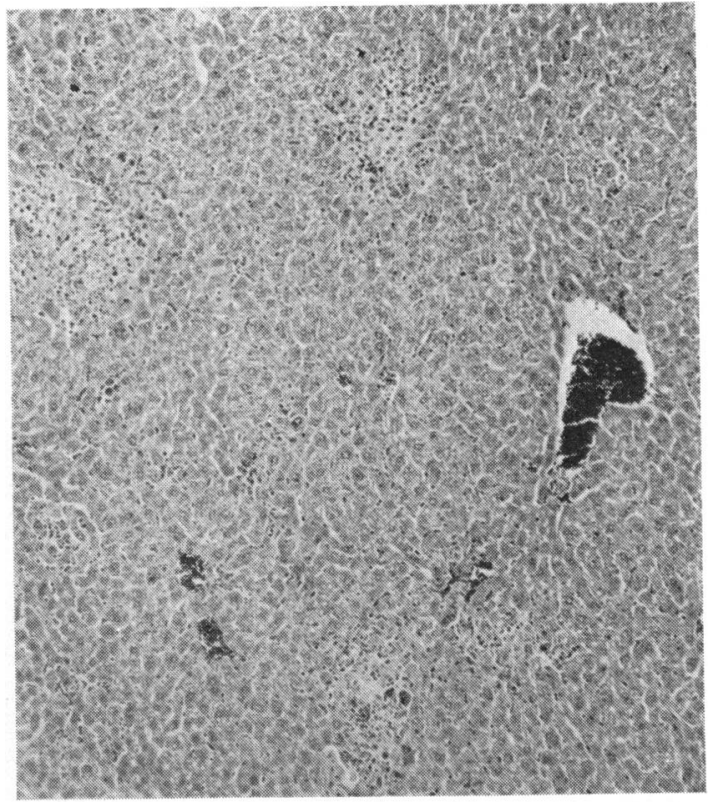

FIG. 5. Liver four days after infection with mouse hepatitis virus. Haematoxvlin and eosin $\times 73$.

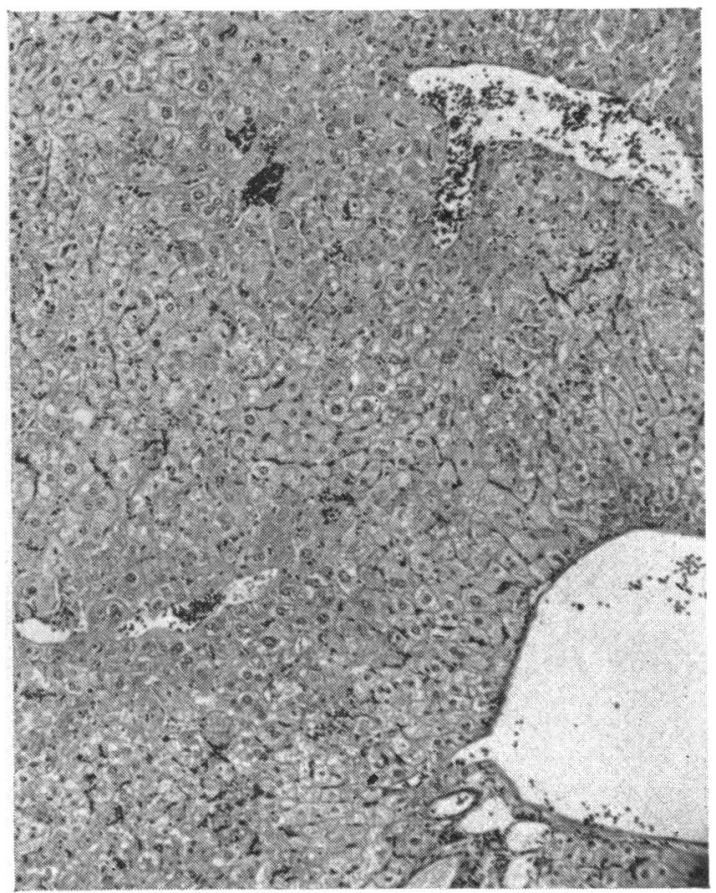

FIG. 7. Liver six days after infection with mouse hepatitis virus. Haematoxylin and eosin $\times 73$. 
(Figs. 4, 5, 6, and 7). The $\mathrm{LD}_{50}$ of ammonium chloride determined on the third, fourth, fifth, and sixth days showed no significant variation from the normal (Table II).

PORTAL-SYSTEMIC COLLATERAL CIRCULATION Oesophageal varices and other collateral circulatory channels appeared in mice with partial portal vein ligation within two weeks of ligation. They were still present at six months. The liver did not change in size, but there was moderate splenic enlargement and an increase in portal pressure from 5.0 $\pm \mathbf{0 . 7}$ to $7.9 \pm 0.6 \mathrm{~cm}$. of water. Microscopically, there was no remarkable change in the liver. The lethal effect of ammonium chloride was significantly decreased two weeks following ligation (Table III). Further studies performed at one and two months in groups of mice maintained on a normal diet and a highprotein diet plus ammonia drinking water revealed no change in ammonia toxicity in comparison with normal animals in the same weight range (Table III).

Mice infected with Schistosoma mansoni and maintained on either a normal laboratory diet or a high-protein diet as above (for the two weeks before determination of the $\mathrm{LD}_{50}$ ) were studied at 12 to 14 weeks following infection. At this time there was marked hepato-splenomegaly and oesophageal varices were present in 30 to $50 \%$ of the animals. The results of liver function tests were previously reported in a similar group of animals (DeWitt and Warren, 1959). Microscopically, there were many pseudo-tubercles in the liver and marked periportal inflammatory cell infiltration (Fig. 8). There was no change in the $\mathrm{LD}_{50}$ of ammonium chloride in these animals (Table III).

PARENCHYMAL DAMAGE AND PORTAL-SYSTEMIC COLLATERAL CIRCULATION A group of animals was studied two weeks after ligation of the common bile duct. At that time, of the 93 mice operated on, there were only 58 survivors. All of these animals had marked hepatomegaly and slight splenomegaly, and

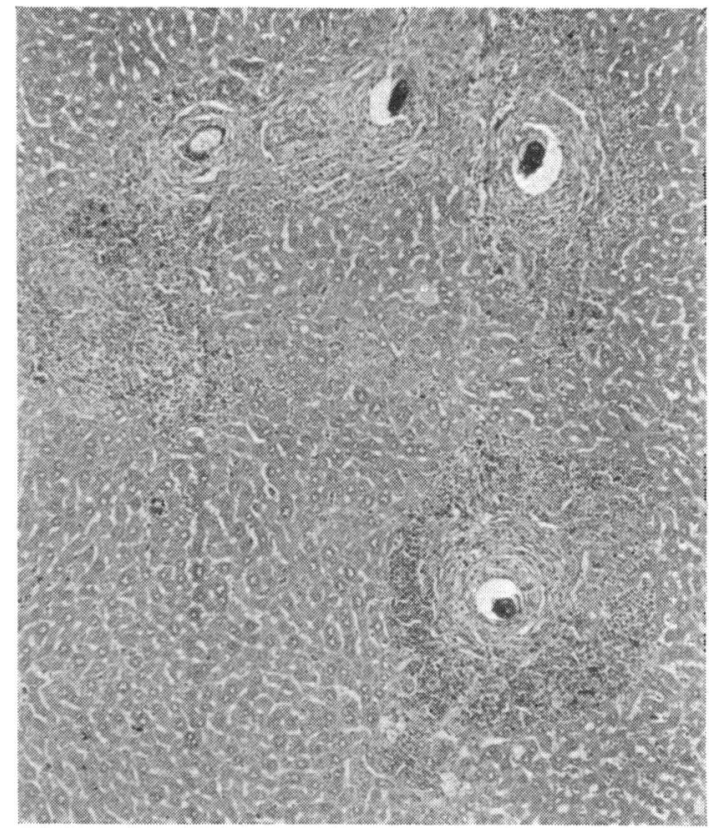

FIG. 8. Liver 12 weeks after infection with Schistosoma mansoni. Haematoxylin and eosin $\times 73$.

$50 \%$ had oesophageal varices. The portal pressure was increased. The total serum bilirubin concentration was greatly raised, being $10 \cdot 5 \pm 0.8$ compared with $0.49 \pm 0.16$ in a group of control mice. Microscopic examination revealed marked enlargement and proliferation of the bile ducts, and large areas of necrosis, fibrosis, and inflammatory cell infiltration (Fig. 9). In spite of these changes there was no increase in ammonia toxicity (Table IV).

Finally, mice with schistosomiasis at the stage in which there was portal hypertension and development of collateral circulation were injected subcutaneously with carbon tetrachloride. They developed marked parenchymal cell destruction.

TABLE III

PORTAL-SYSTEMIC COLLATERAL CIRCULATION AFTER LD $_{50}$ OF AMMONIUM CHLORIDE IN MICE WITH LIVER DISEASE

\begin{tabular}{|c|c|c|c|c|c|c|c|c|}
\hline & $\begin{array}{l}\text { Average } \\
\text { Body } \\
\text { Weight } \\
\text { (kg.) }\end{array}$ & $\begin{array}{l}\text { Estimated } \\
L D_{\mathrm{so}}\end{array}$ & \pm & S.D. & $\begin{array}{l}\text { Expected } \\
L D_{50}\end{array}$ & $\begin{array}{l}\text { Approximate } \\
97.5 \% \\
\text { Confidence } \\
\text { Limit }\end{array}$ & $\begin{array}{l}\text { Approximate } \\
97 \cdot 5 \% \\
\text { Confidence } \\
\text { Limit }\end{array}$ & $\boldsymbol{P}$ \\
\hline $\begin{array}{l}\text { Portal vein ligation } \\
\text { Two weeks } \\
\text { One month } \\
\text { Two months } \\
\text { Two months (high-protein diet) }\end{array}$ & $\begin{array}{l}24 \\
24 \\
26 \\
26\end{array}$ & $\begin{array}{l}921 \\
609 \\
800 \\
876\end{array}$ & $\begin{array}{l} \pm \\
\pm \\
\pm \\
\pm\end{array}$ & $\begin{array}{l}11 \\
79 \\
16 \\
47\end{array}$ & $\begin{array}{l}780 \\
780 \\
810 \\
810\end{array}$ & $\begin{array}{l}895-947 \\
433-785 \\
765-835 \\
770-982\end{array}$ & $\begin{array}{l}733-827 \\
733-827 \\
763-857 \\
763-857\end{array}$ & $\begin{array}{l}<0.05 \\
\text { Insignificant } \\
\text { Insignificant } \\
\text { Insignificant }\end{array}$ \\
\hline $\begin{array}{l}\text { Schistosomiasis } \\
\text { (high-protein diet) }\end{array}$ & $\begin{array}{l}24 \\
30\end{array}$ & $\begin{array}{l}827 \\
867\end{array}$ & $\begin{array}{l} \pm \\
\pm\end{array}$ & $\begin{array}{l}35 \\
24\end{array}$ & $\begin{array}{l}780 \\
875\end{array}$ & $\begin{array}{l}749-905 \\
813-921\end{array}$ & $\begin{array}{l}733-827 \\
795-955\end{array}$ & $\begin{array}{l}\text { Insignificant } \\
\text { Insignificant }\end{array}$ \\
\hline
\end{tabular}


TABLE IV

PARENCHYMAL DAMAGE AND PORTAL-SYSTEMIC COLLATERAL CIRCULATION AFTER LD $_{50}$ OF AMMONIUM CHLORIDE IN MICE WITH LIVER DISEASE

\begin{tabular}{|c|c|c|c|c|c|c|}
\hline $\begin{array}{l}\text { Average } \\
\text { Body } \\
\text { Weight } \\
(\mathrm{kg} .)\end{array}$ & $\begin{array}{l}\text { Estimated } \\
L D_{30}\end{array}$ & \pm & S.D. & $\begin{array}{l}\text { Expected } \\
L D_{50}\end{array}$ & $\begin{array}{l}\text { Approximate } \\
97 \cdot 5 \% \\
\text { Confidence } \\
\text { Limit }\end{array}$ & $\begin{array}{l}\text { Approximate } \\
97 \cdot 5 \% \\
\text { Confidence } \\
\text { Limit }\end{array}$ \\
\hline
\end{tabular}

\begin{tabular}{|c|c|c|c|c|c|c|c|c|}
\hline $\begin{array}{l}\text { Schistosomiasis and carbon } \\
\text { tetrachloride }\end{array}$ & 23 & 766 & \pm & 36 & 765 & $685-847$ & $718-812$ & Insignificant \\
\hline Bile duzt ligation & 22 & 823 & \pm & 30 & 750 & $756-890$ & $703-797$ & Insignificant \\
\hline
\end{tabular}

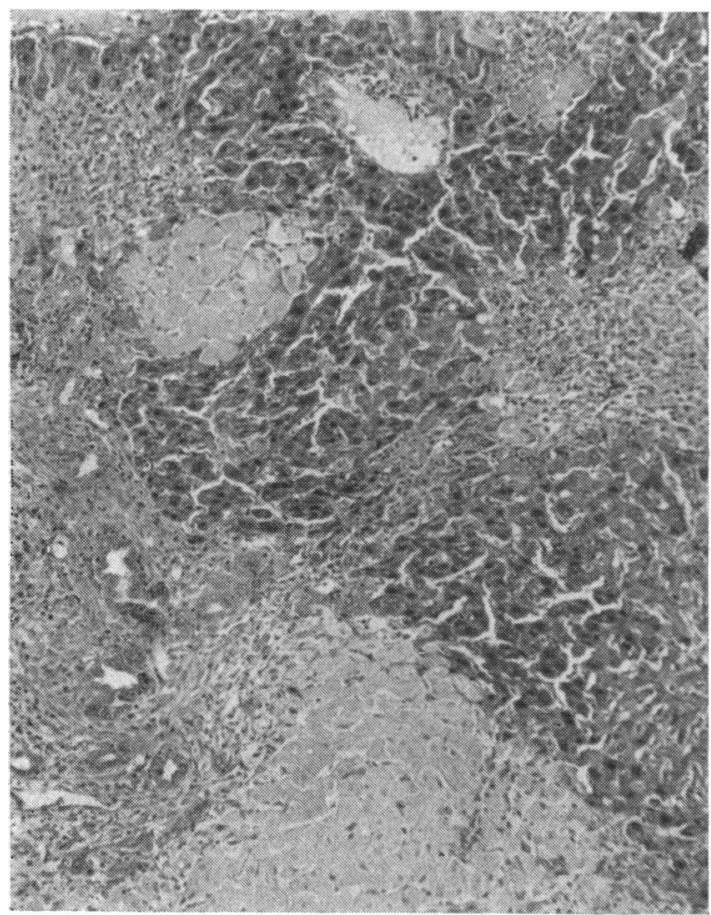

FIG. 9. Liver two weeks after ligation of the common bile duct. Haematoxylin and eosin $\times 73$.

Nevertheless, they reacted in a fashion similar to normal animals when the intravenous $L^{2} D_{50}$ of ammonium chloride was determined (Table IV).

\section{DISCUSSION}

The classical animal model for hepatic coma has been the dog with an Eck fistula suffering from meat intoxication. Although many doubts have been expressed about the validity of this model, a similar procedure (portacaval shunt) in humans with either normal or diseased livers may precipitate hepatic coma or chronic portal-systemic encephalopathy, particularly in the presence of a high-protein diet (McDermott and Adams, 1954; Laidlaw, Read, and Sherlock, 1961). Occasional dogs with Eck fistulae, maintained on a normal laboratory diet, will also become comatose (Bollman, 1961). Spontaneous coma occurs much more frequently, however, in dogs that have undergone hepatic artery ligation shortly after an end-to-side portacaval shunt (Rappaport, Macdonald, and Borowy, 1953).

The original reports describing meat intoxication in dogs with Eck fistulae also incriminated ammonia as the cause of the syndrome (Nencki et al., 1896). In addition, ammonia or ammonia-engendering substances have been shown to precipitate coma in a patient with an Eck fistula (portacaval shunt in a patient with a normal liver) (McDermott and Adams, 1954). The development of hepatic coma in many patients with cirrhosis of the liver or with hepatitis has also been related to high-protein diets and ammonia (Martini, 1961). In spite of this evidence, however, the correlation between hepatic coma and ammonia intoxication in humans remains rather confused (Sherlock, 1961). Many patients with relatively severe liver disease are unharmed by either high-protein diets or oral ammonium compounds, and even intravenous ammonium salts may be well tolerated (Seegmiller, Schwartz, and Davidson, 1954). However, some patients with hepatic derangements appear to exhibit an exquisite sensitivity to dietary protein or to ammoniacontaining substances, and this problem may be precipitated or exacerbated by a portacaval shunt. Laidlaw et al. (1961) believe that they can detect these potentially sensitive patients before operation by their morphine tolerance test.

The interrelations, therefore, between liver disease, hepatic coma, meat-intoxication, and ammonia toxicity remain to be elucidated. Is the access of ammonia to the peripheral circulation the complete answer, or are unknown toxins involved? Does the brain in the presencz of severe hepatic pathology become more susceptible to various metabolic and physiological insults? Finally, does the constant perfusion of the brain by raised concentrations of ammonia or other metabolites in the gut render it 
more sensitive to relatively acute elevations in these substances?

In our experiments, extremely severe parenchymal damage due to carbon tetrachloride injection or infection with mouse hepatitis virus did not increase susceptibility to ammonia. A deficient diet causing severe hepatic fatty change was associated with only a slight increase in ammonia toxicity, barely significant at the $5 \%$ level. Mild cirrhosis induced by prolonged intermittent carbon tetrachloride inhalation seemed to be slightly protective. Animals with portal-systemic collateral circulation due to both partial portal vein ligation and infection with $S$. mansoni were maintained on high-protein diets and ammonia drinking water for as long as two months. (An ammonia tolerance test performed on the mice with schistosomiasis (DeWitt and Warren, 1959) revealed greatly increased passage of an oral dose of ammonium chloride into the peripheral circulation.) Nevertheless, there was no change in the toxicity of intravenous ammonium chloride on comparison with normal control animals. Therefore, prolonged access of ammonia and other metabolites of the gut to the peripheral venous system did not have any effect on acute ammonia toxicity in the mouse. This is similar to the observations of DeRiemer, Hine, and Harper (1955) who found no increase in toxicity upon the intravenous infusions of ammonia into dogs with Eck fistulae. Finally, under the most extreme conditions, a combination of both collateral circulation and severe generalized parenchymal damage, there was no increase in ammonia toxicity.

Although our results are in agreement with the findings in the dog reported by DeRiemer et al. (1955), they do not appear to be similar to the human picture. It is possible that species differences may be a factor, or that the right timing and disease conditions may not have been simulated. Of a large number of patients with liver disease only a very small proportion tend to develop portal-systemic encephalopathy at any given time, and that found in infectious hepatitis, portal-systemic shunt, and chronic cirrhosis may have more than subtle differences. Bollman (1961) has pointed out the extremely complex situation that prevails in relation to the development of meat intoxication in dogs with Eck fistulae. Similar labyrinthine ways are probably present in our path to the understanding of hepatic coma.

\section{REFERENCES}

Bollman, J. L. (1961). The animal with an Eck fistula. Physiol. Rev., 41, 607-621.

Cornfield, J., and Mantel N. (1950). Some new aspects of the application of maximum likelihood to the calculation of the dosage response curve. J. Amer. Statist. Assoc., 45, 181-210.

Daniel, P. M., Prichard, M. M. L., and Reynell, P. C. (1952). The portal circulation in experimental cirrhosis of the liver. J. Path. Bact., 64, 53-60.

DeRiemer, R. H., Hine, D. E., and Harper, H. A. (1955). An evaluation of ammonia intoxication in normal dogs and in dogs having a portacaval anastomosis. Surg. Forum 1954, 5, 205-210.

DeWitt, W. B., and Warren, K. S. (1959). Hepato-splenic schistosomiasis in mice. Amer. J. trop. Med. Hyg., 8, 440-446.

Laidlaw, J., Read, A. E., and Sherlock, S. (1961). Morphine tolerance in hepatic cirrhosis. Gastroenterology, 40, 389-396.

Malloy, H. T., and Evelyn, K. A. (1937). The determination of bilirubin with the photoelectric colorimeter. J. biol. Chem., 119, 481-490.

Martini, G. A. (1961). Die Bedeutung des Blutammoniaks für die Entstehung des Leberkomas. Dtsch. med. Wschr., 86, 13511353.

McDermott, W. V. Jr., and Adams, R. D. (1954). Episodic stupor associated with an Eck fistula in the human with particular reference to the metabolism of ammonia. J. clin. Invest., 33, 1-9.

Nencki, M., Pawlow, J. P., and Zaleski, J. (1896). Ueber den Ammoniakgehalt des Blutes und der Organe und die Harnstoffbildung bei den Säugethieren. Naunyn-Schmiedeberg's Arch. exp. Path. Pharmak., 37, 26-51.

Rappaport, A. M., Macdonald, M. H., and Borowy, Z. J. (1953). Hepatic coma following ischemia of the liver. Surg. Gynec Obstet., 97, 748-762.

Schwartz, R., Phillips, G. B., Seegmiller, J. E., Gabuzda, G. J. Jr., and Davidson, C. S. (1954). Dietary protein in the genesis of hepatic coma. New Engl. J. Med., 251, 685-689.

Seegmiller, J. E., Schwartz, R., and Davidson, C. S. (1954). The plasma "ammonia" and glutamine content in patients with hepatic coma. J. clin. Invest., 33, 984-988.

Sherlock, S. (1961). Hepatic coma. Gastroenterology, 41, 1-8.

Tyor, M. P., and Wilson, W. P. (1958). Peripheral biochemical changes associated with the intravenous administration of ammonium salts in normal subjects. J. Lab. clin. Med., 51, 592-599.

Van Caulaert, C., Deviller, C., and Half,, M. (1932). Troubles provoqués par l'ingestion de sels ammoniacaux chez l'homme atteint de cirrhose de Laennec. C. R. Soc. Biol. (Paris), 111, 739-740.

Walshe, J. M. (1960). Biochemical studies in hepatic coma. Lect. sci. Basis Med., 1958-59, 8, 407-428.

Warren, K. S. (1958). The differential toxicity of ammonium salts. J. clin. Invest., 37, 497-501.

- (1962). pH and ammonia toxicity. In preparation.

Whitaker, W. L. (1946). Portal vein ligation and the Eck fistula in the rat. Proc. Soc. exp. Biol. (N. Y.), 61, 420-423. 